\title{
The Eurasian Economic Union as part of Eurasian (dis)integration
}

\author{
Azhar SERIKKALIYEVA*, Kanat MAKHANOV**
}

\begin{abstract}
Exploring the main cooperation schemes between the member-states of the Eurasian Economic Union (EAEU) within a broader context of the geopolitical processes in the Post-Soviet space, the article intends to discuss the feasibility of integration among Former Soviet countries. The article intends to present the formally announced integration initiatives in the Post-Soviet space (such as the CIS, EurAsEC and EAEU) as part of a de-facto ongoing process of disintegration that started right after the collapse of the Soviet Union. Within this scheme, Russia consistently acts as a generator of a centripetal integration force by proposing different institutional frameworks for integration. However, it is not sufficiently powerful to overcome the centrifugal inertia acquired by the rest of the Post-Soviet states. The article concludes that, in spite of its formal integration purposes, the EAEU is indeed another stage of the ongoing disintegration process in the Post-Soviet space.
\end{abstract}

Keywords: Eurasian Integration, Eurasian Economic Union, Post-Soviet space, Russia, disintegration

\section{Introduction}

Creating a single market of nearly 180 million people, the Eurasian Economic Union (EAEU) was ambitiously announced in 2015 as the largest integration project in the Post-Soviet space. As its name suggests, the project implies a very high degree of integration in which its member-states jointly decide on common trade policy and tariffs to eliminate barriers to the movement of labour and capital between each other, accept common technical standards on commodity production and services, conduct joint economic policy in specified sectors of the economy etc. Inspired by other regional economic unions such as the EU, MERCOSUR, ASEAN and others,

\footnotetext{
* Azhar SERIKKALIYEVA is an Assistant Professor at Al-Farabi Kazakh National University, Almaty, Kazakhstan; e-mail: serikkaliyeva@gmail.com.

${ }^{* *}$ Kanat MAKHANOV is a researcher at the Eurasian Research Institute, Khoja Akhmet Yassawi International Kazakh-Turkish University, Almaty, Kazakhstan; e-mail: kanat.makhanov@eurasian-research.org.
} 
the EAEU was meant to serve the common economic interests of its members by trade liberalization, by creating larger markets for businesses, to reduce transaction costs and enhance trade cooperation. The EAEU came as a result of previous efforts of the founding members (Russia, Kazakhstan and Belarus) aimed at developing trade cooperation by creating a Customs Union in 2011. In 2015, the Customs Union was transformed into the EAEU and Armenia and Kyrgyzstan joined the union later that year.

The roots of the EAEU are limited to the creation of the Customs Union and can be traced back as far as the early 2000s. In 2000, Russia, Kazakhstan, Belarus, Kyrgyzstan and Tajikistan agreed to establish the Eurasian Economic Community (EurAsEC), which also aimed for the economic integration of its member states. The organization helped to implement numerous joint actions that set the foundation of the Customs Union in 2011 and the proper EAEU. In 2014, the EurAsEC was dissolved and its functions were transferred to the newly created EAEU and the EurAsEC simply became useless.

The ideas of economic integration in the Post-Soviet space were also rambling in vague statements in the official documents of the Commonwealth of Independent States (CIS). Although integration was not clearly specified as an objective, one of its functions was fomenting regional integration and it was discussed on the outskirts of official negotiations between the CIS member-states. A keen interest in integration was illustrated at a summit of CIS and EurAsEC heads of state, held in Dushanbe on 5-6 October 2007, which adopted the Concept for Further Development of the CIS and other documents to create a customs union between Russia, Belarus and Kazakhstan and to set up supranational regulatory institutions.

Interestingly, in spite of active negotiations and large amount of efforts spent for establishing the institutional framework of the EAEU, in real terms, it became a solid regional project that would encompass many Post-Soviet states. In fact, most of the goals of the EAEU have either been declarative or politically motivated, which limited its success (Mostafa and Mahmood, 2018). Integration processes in the Eurasian space attract the attention of other states and international organizations. The vast Eurasian space has enormous amounts of natural resources and the countries of this region have a very advantageous geographical location and are important partners of many large economies of the world. In particular, the territories of some Eurasian countries serve as a corridor for transit of highly important primary commodities, as oil and gas. Some states want to set up economic cooperation with the region, consolidate their presence there and strengthen their influence on the ongoing integration processes. The aggregate economic and political potential of states allows them to take a stronger position in the international arena.

This article intends to study the EAEU in the broader context of integration in the Post-Soviet space by embedding the EAEU and its premises to the previous formal regional organizations. Considering the framework of the EAEU within the context of geopolitical shifts in the Post-Soviet space, it tries to identify logical 
linkages between the EAEU and frameworks of interaction between the Post-Soviet states. The study also assesses some basic economic dimensions of the EAEU, contrasting them with the formally declared aims of the integration initiative. By doing so, the research seeks to shed light on the fundamental forces that have been very active in shaping the regional cooperation in the Post-Soviet space over the last three decades.

\section{Theoretical aspects of the Eurasian integration and methodology}

It is worth mentioning that the term "Eurasia" became widely used after the collapse of the USSR and started to be used even more frequently in political contexts in the early 2000s. The etymology of the word has a deep historical, political and sociocultural meaning for Russia. The origin of the Eurasian concept can be traced back to works written in the 1920s by Russian linguist and ethnographer Nikolai Troubetzkoy and Russian geographer Petr Savicky (1895-1968). The Eurasianism became a source of inspiration for Russian identity by offering a feeling of belonging to a new Eurasian civilization as opposed to westernism. The Eurasian concept gained a new geopolitical meaning thanks to the works of well known Russian scholars, such as Alexandr Panarin and Alexandr Dugin. The concept coincided with Russia's new geopolitical line taken in the 2000s, breathing life into Eurasianism and into the more recent interpretation often referred to as Neo-Eurasianism (Laruelle, 2004).

Economic integration is basically a continuation of the process of liberalization of international economic relations. Bela Balassa (1928-1997), a professor of political economy at John Hopkins University, was one of the most productive students of economic integration. Drawing on the work of Jacob Viner and others, Balassa made a major contribution to our understanding of the effects of integration on trade and other economic activities in the 1960s and 1970s. In the introductory chapter to his important work, The Theory of Economic Integration (1967), Balassa defines economic integration, identifies its main stages, discusses political and ideological aspects of the integration process, and specifies what he means by "economic welfare". According to the theory of Balassa, the term economic integration can be understood both as a process and a state of affairs. As a process, economic integration covers measures for the elimination of discrimination between economic units which belong to different countries. As a state of affairs, it represents the absence of various forms of discrimination between national economies (Hosny, 2013).

Bela Balassa identifies five stages of integration:

- $\quad$ The free trade zone - assumes the elimination of tariffs between member- states;

- The Customs Union (CU) - assumes the introduction of Common Customs Tariff (CCT);

- A uniform market - the restrictions for free movement of factors are eliminated;

- The economic union - the process of harmonization of economic policies; 
- Full economic integration - monetary, fiscal, social and counter-cyclical functions are unified under a political union with very limited sovereignty (Balassa, 1961).

In reality, of course, such sequence optional compliance and the integration process may start immediately with the formation of the Customs Union. For example, the countries which originally have identical external tariffs can establish a CCT.

B. Balassa identified three separate directions of influence of integration on welfare: trade, terms of trade and movement of factors of production (Hosny, 2013). He stated that trade integration can reduce the price difference of factors of production within the Customs Union area. However, trade is not a sufficient condition for full equalization of prices. Thus, he supported the idea of creating a common market, arguing that the mobility of labour, capital and entrepreneurial resources leads to a more efficient use of economic resources. Besides, he has predicted the future development of the European integration from the Customs Union to the political union. His statement that a political association must precede monetary unification and that the opposite can lead to an unfavorable result proved to be true during the 20082009 crisis. The ideas of Balass were widely used during the development of the New Trade Theory in the late 1980s and early 1990s (Hosny, 2013).

A significant contribution to the development of the theory of economic integration was made by C. Cooper and B. Massell (Cooper and Massell, 1965). They noted that the analysis of the Customs Union has to be focused on the scale effect, change of terms of trade, problems of the balance of payments, and other important indicators. They create the idea of Partial Customs Union, which is identified as an agreement of several countries with the introduction of CCT, but with partially free domestic trade. The influence of such Customs Union will depend on the rules of its formation. The rules include placement of production, intra-union trade and a system of compensation. The higher the flexibility of the union-forming rules, the higher the potential benefits for participating countries. Customs Union that provides subsidies or other effective policies can guarantee benefits to all participants.

The trade and economic integration has a positive impact on economic growth and on attracting foreign direct investment (Krugman et al., 2011; Sachs, 2000). The analysis of J. Frankel and D. Romer (Frankel and Romer, 1999) identified that trade raises incomes. Trade stimulates income growth through the accumulation of physical and human capital and promotes productivity growth (Panagariya, 2000). Moreover, domestic trade also promotes population's income growth. The analysis of D. Spasford and S. Garikipati (Sapsford and Garikipati, 2006) showed that trade promotes economic growth, which contributes to poverty reduction. However, the performance of the trade-growth-poverty reduction chain requires an appropriate economic policy. According to Yong Joon Jang (Yong, 2011), economic integration shows a positive impact on attracting foreign investment. However, trade agreements between developed countries can lead to the opposite effect (Benini and Plummer, 2008).

Thus, the trade and economic effects of regional economic integration are positive. The formation of integration opens a wide range of opportunities (Wild and 
Wild, 2014), such as the increase in mutual trade, in particular, exports, the attraction of foreign investments and, as a result, an increase in employment and decrease of the level of poverty (Robson, 1998). However, it is necessary to remember that the achievement of the planned purposes can only be successful if a proper economic policy is implemented (Baier et al., 2008), i.e. one which would include short-term plans and long-term strategy, a risk management system, and also, if the integration policy is based on the experience of more advanced countries.

One of the features of the Post-Soviet space that makes if different from other regions and regional cooperation schemes is the huge size differences of the countries and the overwhelming dominance of Russia in every aspect, which is not counterbalanced by other potential members of integration in the region (Kirkham, 2016). The presence of Russia in practically all important regional organizations is one of the factors that makes it difficult to establish equitable integrational frameworks that would ensure the equal representation of the interests of all members (Pincu and Stan, 2020). Moreover, the Eurasian integration initiative is being built within the limits of the Post-Soviet space, which is a source of a certain level of suspicion and even outrage towards Russia and its recent aspirations to resuscitate Soviet geopolitical visions. Another factor affecting the integration, as well as any other regional interaction between the Post-Soviet states is the poor quality of institutions and their further deterioration. The EAEU consists of newly created authoritarian states with limited human rights and political freedoms, which overshadows the attractiveness of the common market of the union in terms of foreign investments and limits, to a certain extent, cooperation opportunities with democratic states (Mostafa and Mahmood, 2018).

The research aim addressed by this study is to analyze the consistency of the integration processes being promoted within the EAEU framework with the real geopolitical and economic processes that the EAEU member-states, as well as the Post-Soviet space are involved in. The study mainly follows a qualitative approach backed with data from official reports, open source statistics, reports, official statements and documents, as well as academic sources. All necessary statistical information is presented in tables.

\section{Literature review}

In recent years, the performance and prospects of the EAEU and the Eurasian integration, in general, have been well studied and assessed in different fields. However, a relatively small proportion of the existing literature studies the Eurasian integration from the point of view of international regional organizations, putting it in a context of regionalism and broader regional cooperation in the Post-Soviet space and Eurasia.

Within a short period of time, the Post-Soviet space has seen a highly active formation of regional organization. At the same time, regional organizations which 
have emerged in post-Soviet Eurasia have a strong historical dimension (Libman and Obydenkova, 2020). The Eurasian economic integration was preceded by several other organizations and mutual acts of commitment by the heads of states. The basic ideas of the EAEU had already been proposed in the 1990s and 2000s, when ideas of creating a Customs Union and Common Economic Space were widespread among Post-Soviet states (Vinokurov, 2017). However, it was only in 2011 when participating states managed to reach tangible results in establishing the Customs Union. The implementation of regional organizations in authoritarian states happens to be more reliant on intermediate economic dependence rather than on strong economic ties (Libman and Vinokurov, 2018). Regional international organizations established by authoritarian regimes can prolong the survival of regimes in its member states. From this point of view, the internal political structure of the member-states might have been one of the criteria for entering the EAEU (Libman and Obydenkova, 2018). In terms of its formal institutional framework, the EAEU imitates the EU, which turns out to be detrimental for the external ties of the EAEU and even for EU-EAEU interaction (Libman, 2019). At the same time, unlike the EU, the EAEU has rather flexible membership mechanisms, which does not constitute a major constraint for the Eurasian countries' participation in the multilateral trade systems (Libman, 2020). The official active involvement of the Post-Soviet states in regionalism is often not backed with real actions and commitments (Libman and Vinokurov, 2012). Therefore, officially declared intentions and actions of integration are not generally understood as absolute commitments.

Unlike in most other regional integration projects, the pursued gains of the member-states in the EAEU tend to differ a lot from state to state. In its essence, the EAEU can be considered a hybrid half-economic and half-political project. Nevertheless, it is understood by Russia as a success because economic aspects are less important (Sergi, 2018). The rest of the member-states, on the other hand, prioritize other more economic, strategic and security benefits. Besides interlinked supply chains with Russia (Vinokurov, 2017), Kazakhstan's whole oil industry in its western regions relied on Russian pipelines (Pomfret, 2005). Kyrgyzstan's membership in the Eurasian Economic Union (EEU) is primarily motivated by socioeconomic reasons (Peyrouse, 2015). Armenia's rapid accession to the EAEU was largely motivated by desires for strategic gains and Russia's support in its longlasting conflict with Azerbaijan (Mostafa and Mahmood, 2018).

\section{Previously established regional organizations and Eurasian (dis)integration}

The timeline of the (dis)integration processes in the Post-Soviet Eurasia started immediately after the collapse of the USSR as the newly independent states started to seek new forms of cooperation to resolve acute socio-economic problems. There were several factors that motivated the Post-Soviet states to seek assistance 
through cooperation with other newly proclaimed republics in the first place. 1 Very scarce financial resources to cope with urgent socio-economic necessities. 2 Highly interlinked supply chains and economic connections. 3 - In most of the newly independent republics, the ruling political elites remained in power or had the same socio-political backgrounds as previous communist elites. The combined effect of these factors prevailed over the centrifugal impetus that the majority of the PostSoviet republics acquired at the moment of the collapse of the Soviet Union providing integration momentum for a short period.

\subsection{The Commonwealth of Independent States}

The CIS became the first formal regional organization covering almost the whole Post-Soviet space, with the exception of the three Baltic States. In fact, the CIS should be considered as the first significant step taken by Post-Soviet states towards regional integration. Unlike subsequent organizations though, regional integration between the member-states was not the primary objective of the CIS. For instance, the word "integration" is mentioned only twice in the Charter of the Commonwealth of Independent States adopted in 1993. Instead, the organization was mainly aimed at developing cooperation. However, it should be admitted that during the first half of the 1990s the CIS member-states were involved in certain integration processes within the organization. On April 1, 1994, all members of the CIS, except for Turkmenistan, signed an Agreement on creating an FTA. However, it was never implemented until 2011.

Despite mainly being a consultative organization without stringent binding mechanisms over the last two decades, the CIS has been in decline. It should be mentioned that the CIS is a shrinking organization and that, since 1994, the number of fully active members of the organization was reduced from twelve to nine. Moreover, the contraction of the organization came as a result of full-scale military conflicts between member-states. In August, 2008, Georgia immediately abandoned the CIS after a war with Russia, which led to a de facto loss of control by Georgia over two of its provinces. Similarly, after the Russo-Ukrainian military conflict begun in February, 2014, Ukraine started to suspend the agreements of the CIS up to the point where it abandoned the organization de facto. Military conflicts between CIS member-states have not only shattered very essence of the organization but also prompted some of its members to accelerate their previously declared policies of European integration at the expense of close ties with Russia and integration within the CIS. Besides Georgia and Ukraine, Moldova is also one of the formal CIS members that is ambitiously taking steps on the path to European integration. Although it is one of the active members of the CIS, its membership in the organization is largely motivated by benefits from transportation and preferential trade with other member-states. European integration is an absolute priority for Moldova, an aspect which became clear with the elections of the current president, 
Maia Sandu, and it would clearly easily abandon its CIS membership whenever necessary in order to ensure the implementation of European integration.

\section{Table 1. Evolution of the Commonwealth of Independent States}

\begin{tabular}{ll}
\hline Date & Important events \\
\hline 08.12.1991 & Belarus, Russia and Ukraine signed the Agreement on Establishing the CIS. \\
\hline 21.12 .1991 & $\begin{array}{l}\text { Kazakhstan, Turkmenistan, Uzbekistan, Kyrgyzstan, Tajikistan, Armenia, } \\
\text { Azerbaijan and Moldova signed the Alma-Ata Protocol, which expanded the } \\
\text { CIS to these states. }\end{array}$ \\
\hline 22.01 .1993 & $\begin{array}{l}\text { All members, except for Ukraine and Turkmenistan, signed the Charter } \\
\text { (Statutes) of the CIS, setting up the different institutions of the CIS, their } \\
\text { functions, the rules and statutes of the CIS. }\end{array}$ \\
\hline 15.04 .1994 & $\begin{array}{l}\text { All members, except for Turkmenistan, signed the agreement on establishing } \\
\text { a Free Trade Area (FTA) within CIS. }\end{array}$ \\
\hline 26.05 .1995 & $\begin{array}{l}\text { CIS leaders signed the Convention on the Inter-Parliamentary Assembly of } \\
\text { Member Nations of the Commonwealth of Independent States, eventually } \\
\text { ratified by nine parliaments. }\end{array}$ \\
\hline 1994 & $\begin{array}{l}\text { The Verkhovna Rada of Ukraine joined the Inter-Parliamentary Assembly of } \\
\text { Member Nations of the CIS. }\end{array}$ \\
\hline 18.08 .2008 & Georgia withdrew from the CIS. \\
\hline 18.10 .2011 & An agreement was signed on the creation of a free trade zone within the CIS \\
\hline 19.05 .2018 & Ukraine formally ended its participation in CIS statutory bodies.
\end{tabular}

Source: Authors' representation based on data from cis.minsk.by ${ }^{1}$

Not all Central Asian states are currently full members of the CIS. Since August 2005, Turkmenistan has withdrawn its full membership of the CIS and received the status of an associated observer member which, in fact, reduces its participation in the organization to almost nothing. With this status, Turkmenistan can actively participate in the formal meetings of the organization, but it does not allow Turkmenistan to be engaged in important agreements signed within the framework of the commonwealth. The fact that one of the member-states of the CIS preferred de facto isolationism over membership in the organization is a discrediting factor for the organization as well as another sign of the prevalence of disintegration trends in the Post-Soviet Eurasia.

\subsection{The Eurasian Economic Community}

The Eurasian Economic Community (EurAsEC) was another institutional attempt to initiate an integration process. Unlike the CIS, the EurAsEC openly

1 Cis.minsk.by (2020), About the Commonwealth (retrieved from https://cis.minsk.by/ site/about-cis). 
declared regional economic integration as its goal. In 2001, the main bodies of the community, among which the Integration Committee, were established. This was a permanent body of the EurAsEC, which included deputy heads of government of the EurAsEC states. The main tasks of the Integration Committee included ensuring the integration process by monitoring the interaction between the EurAsEC bodies, preparing proposals for the agenda of meetings of the Interstate Council, as well as draft decisions and documents, monitoring the implementation of decisions adopted by the Interstate Council. It is important to note that the number of member-states of the EurAsEC was only five: Russia, Kazakhstan, Belarus, Kyrgyzstan, and Tajikistan. Uzbekistan was one of the member-states of the EurAsEC for a short period, from January, 2006 to December, 2008.

\section{Table 2. Key events in the timeline of the Eurasian Economic Community}

\begin{tabular}{ll}
\hline Years & Important events \\
\hline 10.10 .2000 & $\begin{array}{l}\text { The heads of state of Russia, Kazakhstan, Belarus, Kyrgyzstan, } \\
\text { and Tajikistan signed an Agreement on the establishment of the } \\
\text { Eurasian Economic Community. }\end{array}$ \\
\hline December, 2003 & $\begin{array}{l}\text { The EurAsEC was granted observer status at the UN General } \\
\text { Assembly. }\end{array}$ \\
\hline January, 2006 & Uzbekistan's accession to the EurAsEC. \\
\hline August, 2006 & $\begin{array}{l}\text { Russia, Kazakhstan and Belarus decided to create a Customs } \\
\text { Union. }\end{array}$ \\
\hline 12.12 .2008 & $\begin{array}{l}\text { The action plan for the formation of the Customs Union was } \\
\text { designed for three years. It was also decided to form a } \\
\text { Commission of the Customs Union - a supranational body. }\end{array}$ \\
\hline December, 2010 & $\begin{array}{l}\text { Agreements were reached on the creation of the EAEU on the } \\
\text { basis of the Common Economic Space of Russia, Belarus and } \\
\text { Kazakhstan. }\end{array}$ \\
\hline July, 2010 & $\begin{array}{l}\text { The Customs Union of Russia, Kazakhstan and Belarus came into } \\
\text { function. }\end{array}$ \\
\hline 10.10 .2014 & $\begin{array}{l}\text { The heads of state of Russia, Kazakhstan, Belarus, Kyrgyzstan } \\
\text { and Tajikistan signed documents on dissolving the EurAsEC due } \\
\text { to the beginning of the functioning of the EAEU from } \\
\text { 01.01.2015. }\end{array}$
\end{tabular}

Source: Authors' representation based on data from Eurasian Economic Commission (2019) ${ }^{2}$, cis.minsk.by $(2020)^{3}$.

2 Eurasian Economic Commission (2019), National accounts (retrieved from http://www.eurasiancommission.org/ru/act/integr_i_makroec/dep_stat/econstat/Pages/natio nal.aspx)

${ }^{3}$ Cis.minsk.by (2020), About the Commonwealth (retrieved from https://cis.minsk.by/ site/about-cis). 
The main function of the EurAsEC was to be reorganized into another stage of integration. In 2010, the Customs Union of Russia, Kazakhstan and Belarus came into function with the help of the EurAsEC. The three states abolished tariffs on mutual trade and adopted common tariffs on trade with other countries. However, the final and most important goal of the EurAsEC was to establish the EAEU. During the summit of the EurAsEC held in October 2011, Vladimir Putin, who was the Prime Minister of Russia at that time, announced the start of implementation of plans to establish the EAEU.

\subsection{The Eurasian Economic Union}

Currently, the Eurasian Economic Union is considered to be the culmination of the Eurasian integration. However, it is important to note that it currently only has five full-members: Russia, Kazakhstan, Belarus, Armenia and Kyrgyzstan. Hence, in the larger context of Eurasia, most Post-Soviet states remained outside the EAEU. In fact, from the early 1990s, the number of countries willing to participate in large integration projects led by Russia kept decreasing. The decline extends not only to the number of official members of the EAEU, but also to other different dimensions that are difficult to quantify.

\section{Table 3. Timeline of formation of the Eurasian Economic Union}

\begin{tabular}{ll}
\hline Year & Event \\
\hline 2010 & Belarus, Kazakhstan, Russia launched the Customs Union. \\
\hline 2011 & $\begin{array}{l}\text { Belarus, Kazakhstan, Russia signed the Declaration on the Eurasian } \\
\text { economic integration and the Agreement on the Eurasian Economic } \\
\text { Commission. }\end{array}$ \\
\hline 2012 & $\begin{array}{l}\text { The Eurasian Economic Commission began its work with headquarters } \\
\text { in Moscow. }\end{array}$ \\
\hline 2015 & The EAEU came into force \\
\hline 2015 & $\begin{array}{l}\text { Belarus, Kazakhstan, Russia, Armenia and Kyrgyzstan signed an FTA } \\
\text { agreement with Vietnam. }\end{array}$ \\
\hline
\end{tabular}

Source: Khitakhunov et al., (2016)

Ironically, it can be stated that the EAEU is, in fact, a reflection of the deep tectonic processes of disintegration in the Post-Soviet Eurasia. This statement can be supported from two different perspectives. The first one is a geopolitical standpoint. It took nearly 25 years for the EAEU to be established and start to properly function whereas the workload done by the member-states to build the legal framework and harmonize the necessary standards is not that big. The sluggishness of the institutional development of the EAEU as well as of previous organizations are primarily caused by the lack of political motivation and willingness of the Post-Soviet states to be take 
part in regional integration projects with the participation of Russia, in particular. Currently, Ukraine, Moldova and Georgia are making great efforts on their way towards the European integration. Not all Central Asian states opted for joining the EAEU. Turkmenistan has taken an isolationist stance and firmly decided not to join the EAEU. It even changed its participation in the CIS with a nominal observer status. Uzbekistan also decided not to be involved in the Eurasian integration in spite of its close ties with Russia, Kazakhstan and Kyrgyzstan. Even Tajikistan still prefers to stand aside in spite of its high dependence on Russia in sensitive issues such as labour migration and security. So, the fact that Russia positions itself as an imitator or key player in the EAEU causes resentment among many Post-Soviet states, thus making it difficult to enhance regional integration processes.

Table 4. Some key economic indicators of the EAEU, 2019

\begin{tabular}{lllll}
\hline & \multicolumn{2}{l}{ GDP nominal billion } & \multicolumn{2}{l}{ Mutual trade turnover } \\
\hline & $\begin{array}{l}\text { Amount } \\
\text { USD) }\end{array}$ & (bln. & $\%$ share & \multicolumn{2}{c}{$\begin{array}{l}\text { Amount } \\
\text { (mln. USD) }\end{array}$} & $\%$ share \\
\hline EAEU & $1,966.7$ & $100.0 \%$ & $61,633.9$ & $100.0 \%$ \\
\hline Russia & $1,699.9$ & $86.4 \%$ & $39,247.2$ & $63.7 \%$ \\
\hline Kazakhstan & 181.7 & $9.2 \%$ & $6,406.2$ & $10.4 \%$ \\
\hline Belarus & 63.1 & $3.2 \%$ & $14,569.6$ & $23.6 \%$ \\
\hline Armenia & 13.7 & $0.4 \%$ & 769.2 & $1.3 \%$ \\
\hline Kyrgyzstan & 8.4 & $0.7 \%$ & 641.7 & $1.0 \%$ \\
\hline $\begin{array}{l}\text { Source: Authors' representation based on data from Eurasian Economic Commission } \\
(2019)^{4} \text {, World Bank data }(2019)^{5}\end{array}$
\end{tabular}

The aspect revealing the disintegration processes in the Post-Soviet Eurasia is the economic factor. In this regard, it should be admitted that, in spite of significant political efforts and institutional investments, fundamental economic processes do not support the regional integration projects. For instance, even the mutual trade of the five current members of the EAEU only accounts for about $7.7 \%$ in their total trade. In other words, the combined total trade of Russia, Kazakhstan, Belarus, Armenia and Kyrgyzstan ( $\$ 733.9$ billion) outnumbers the combined mutual trade ( $\$ 61.6$ billion) by a factor of eight. It should be admitted, though, that in 2014, before the EAEU was created, the mutual trade only accounted for about $5.8 \%$ in the total foreign trade of the current EAEU member-states. However, this clearly shows that the economies of the EAEU are outward-oriented. Despite a small gain in mutual

4 National accounts (retrieved from http://www.eurasiancommission.org/ru/act/ integr_i_makroec/dep_stat/econstat/Pages/national.aspx)

5 GDP (retrieved from current US\$, https://data.worldbank.org/ indicator/NY.GDP.MKTP.CD). 
trade since 2015 , on a longer timescale, the mutual trade gradually decreases relative to the total trade of the EAEU members.

\section{Figure 1. Comparison of combined mutual and eternal trade of the five EAEU member-states}

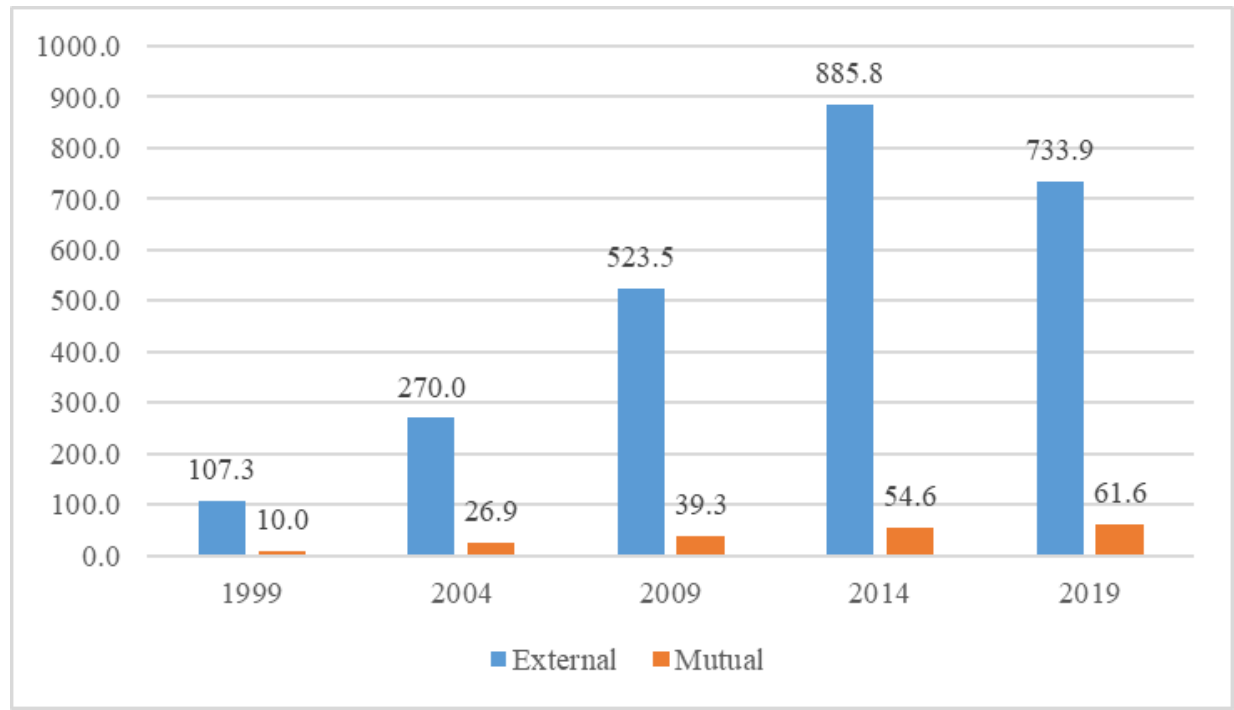

Source: Authors' representation based on data from UN Comtrade ${ }^{6}$

These trends are not only limited to the EAEU member-states. The same is true when we speak about most other Post-Soviet states. Moreover, the trade and economic relations between some Post-Soviet states have been severely affected by conflicts and geopolitical conformation like in cases of the Russia-Ukrainian war of 2014 and Russo-Georgian war in 2008. For instance, the trade between Russia and Ukraine quickly dropped from $\$ 38.3$ billion in 2013 to $\$ 12.3$ billion in 2015 . The trade between Russia and Georgia reduced from \$620 million in 2007 to \$226 million in 2009. There is little and diminishing economic grounds for regional integration projects in the Post-Soviet space as whole. For instance, all current members of the CIS, except for Uzbekistan, Azerbaijan and Turkmenistan, have signed the FTA which implies reduced import tariffs for a wide range of commodities. However, the size of the mutual trade among the current members of the CIS FTA is only around \$105.1 billion, which only accounts for $11.9 \%$ in their total trade ( $\$ 883.5$ billion). In other words, the CIS member-states trade a lot more with the outside world than with each other and this difference tends to grow over time. Thus, from 2010 to 2019 , the sum of the total external trade of the CIS FTA

${ }^{6}$ UN Comtrade Database (retrieved from https://comtrade.un.org/data/). 
members has grown by $23.8 \%$, while the mutual trade during the same period has only increased by $6.9 \%$.

\section{Conclusions}

The EAEU has become the first functional regional integration project in the Post-Soviet Eurasia. Having said this, we should bear in mind that the official manifestation of the processes of institutional formation of regional organizations in the Post-Soviet space does not always accurately reflect the real shifts in regionalism. In the case of the EAEU, we can state that the first steps towards its legal and institutional establishment had been taken as early as in the first half of the 1990s within the framework of the CIS. Despite strong and clearcut disintegration trends changed with the independentist spirit that marked the collapse of the USSR, the gravity of socio-economic burdens prevailed, making the newly-created republics seek cooperation with each other. These processes fueled the organizational dynamics inside the CIS during the first half of the 1990s. However, as soon as the CIS member-states managed to settle the severe and pressing socio-economic issues, by the mid-1990s, the formational activity inside the CIS started to decelerate. The FTA agreement added on the agenda in 1994 was never signed until 2011 in spite of member-states' formal approval. None of them was interested in further strengthening the CIS. It was exactly at this point when the Eurasian disintegration started and the geography of subsequent regional organizations in the Post-Soviet Eurasia has kept shrinking since then.

\section{References}

Baier, S.L., Bergstrand, J.H., Egger, P. and McLaughlin, P.A. (2008), Do Economic Integration Agreements Actually Work? Issues in Understanding the Causes and Consequences of the Growth of Regionalism, The World Economy, 31(4), pp. 461497. https://doi.org/10.1111/j.1467-9701.2008.01092.x

Balassa, B. (1961), The Theory of Economic Integration, London: Homewood and Irwin.

Benini, R. and Plummer, M.G. (2008), Regionalism and multilateralism: crucial issues in the debate on RTAs, Economic Change and Restructuring, 41(4), pp. 267-287. https://doi.org/10.1007/s10644-008-9068-y

Cis.minsk.by (2020), About the Commonwealth (retrieved from https://cis.minsk.by/site/about-cis).

Cooper, C.A. and Massell, B.F. (1965), Towards a General Theory of Customs Union for Developing Countries, Journal of Political Economy, 73(5), pp. 461-476. https://doi.org/10.1086/259070 
Eurasian Development Bank Centre for Integration Studies (2016), The European Union and the Eurasian Economic Union: A long-term dialogue and prospects for an agreement, 2015, Saint Petersburg (retrieved from https://publications.hse.ru/books/198371260)

Frankel, J.A. and Romer, D. (1999), Does trade cause growth?, American Economic Review, 89(3), pp. 379-399. https://doi.org/10.1257/aer.89.3.379

Hosny, A.S. (2013), Theories of Economic Integration: A Survey of the Economic and Political Literature, International Journal of Economy, Management and Social Sciences, 2(5), pp. 133-155.

Khitakhunov, A., Mukhamediyev, B. and Pomfret R. (2016), Eurasian Economic Union: Present and Future Perspectives, Economic Change and Restructuring, (50)1, pp. 5977. https://doi.org/10.1007/s10644-016-9182-1

Kirkham, K. (2016), The formation of the Eurasian Economic Union: How successful is the Russian regional hegemony?, Journal of Eurasian Studies, 7(2), pp. 111-128. https://doi.org/10.1016/j.euras.2015.06.002

Krugman, P.R., Obstfeld, M. and Melitz, M. (2011), International economics theory and policy, (11th ed), London: Pearson.

Laruelle, M. (2004), The two faces of Contemporary Eurasianism: An imperial version of Russian nationalism, Nationalities Papers, 32(1), pp. 115-136. https://doi.org/10.1080/0090599042000186197

Libman, A. and Obydenkova, A. (2018), Regional international organizations as a strategy of autocracy: the Eurasian Economic Union and Russian foreign policy, International Affairs, 94(5), pp. 1037-1058. https://doi.org/10.1093/ia/iiy147

Libman, A. and Obydenkova, A. (2020), Global governance and interaction between international institutions: The challenge of the Eurasian International Organizations, Post-Communist Economies, 33(2-3), pp. 47-149. https://doi.org/10.1080/14631377.2020.1793585

Libman, A. and Vinokurov, E. (2012), Eurasian Economic Union: Why now? Will it work? Is it enough?, 13 Whitehead J. Dipl. and Int'l Rel, 29, pp. 29-30.

Libman, A. and Vinokurov, E. (2018), Autocracies and regional integration: the Eurasian case, Post-Communist Economies, 30(3), pp. 334-364. https://doi.org/10.1080/14631377.2018.1442057

Libman, A.M. (2019), Learning from the European Union? Eurasian regionalism and the "Global Script", Outlines of Global Transformations: Politics, Economics, Law, 12(2), pp. 247-268. https://doi.org/10.23932/2542-0240-2019-12-2-247-268

Libman, A.M. (2020), Eurasian regionalism and the WTO: A building block or a stumbling stone?, Post-Communist Economies, 33(2-3), pp. 246-264. https://doi.org/10.1080/14631377.2020.1793589

Mostafa, G. and Mahmood, M. (2018), Eurasian Economic Union: Evolution, challenges and possible future directions, Journal of Eurasian Studies, 9(2018), pp. 163-172. https://doi.org/10.1016/j.euras.2018.05.001 
Panagariya, A. (2000), Preferential trade liberalization: the traditional theory and new developments, Journal of Economic Literature, 38(2), pp. 287-331. https://doi.org/10.1257/jel.38.2.287

Peyrouse, S. (2015), Kyrgyzstan's membership in the Eurasian Economic Union: A marriage of convenience?, Russian Analytical Digest, 165(10), pp. 10-12.

Pincu, B.N. and Stan, A.D. (2020), Economic integration struggles in the post-soviet space: the organization for democracy and economic development (GUAM), International Relations, 1(19), pp. 19-33.

Pomfret, R. (2005), Kazakhstan's economy since independence: Does the oil boom offer a second chance for sustainable development?, Europe-Asia Studies, 57(6), pp. 859976. https://doi.org/10.1080/09668130500199467

Robson, P. (1998), International Integration Economics, London: Routledge. https://doi.org/10.4324/9780203019603

Sachs, J. (2000), Globalization and Patterns of Economic Development, Review of World Economics, 136(4), pp. 579-600.

Sapsford, D. and Garikipati, S. (2006), Trade liberalization, economic development and poverty alleviation, The World Economy, 29(11), pp. 1571-1579. https://doi.org/10.1111/j.1467-9701.2006.00855.x

Sergi, B.S. (2018), Putin's and Russian-led Eurasian Economic Union: A hybrid halfeconomics and half-political "Janus Bifrons", Journal of Eurasian Studies, 9(2018), pp. 52-60. https://doi.org/10.1016/j.euras.2017.12.005

UN Comtrade (2020), UN Comtrade Database (retrieved from https://comtrade.un.org/data/).

Vinokurov, E. (2017), Eurasian Economic Union: Current state and preliminary results, Russian Journal of Economics, 3(2017), pp. 54-70. https://doi.org/10.1016/j.ruje.2017.02.004

Wild, J.J. and Wild K.L. (2014), International Business the Challenges of Globalization (6th ed.), Beijing: China Renmin university press, p. 468.

Yong J.J. (2011), The impact of bilateral free trade agreements on bilateral foreign direct investment among developed countries, East Asian Economic Review, 34(9), pp. 1628-1651. https://doi.org/10.1111/j.1467-9701.2011.01356.x 